\title{
Ten Years of Tau-Targeted Immunotherapy: The Path Walked and the Roads Ahead
}

\author{
Petr Novak ${ }^{1,2}$, Eva Kontsekova ${ }^{1,3}$, Norbert Zilka ${ }^{1,3}$ and Michal Novak ${ }^{1,4 *}$ \\ ${ }^{1}$ Institute of Neuroimmunology, Slovak Academy of Sciences, Bratislava, Slovakia, ${ }^{2}$ AXON Neuroscience CRM Services SE, \\ Bratislava, Slovakia, ${ }^{3}$ AXON Neuroscience R\&D Services SE, Bratislava, Slovakia, ${ }^{4}$ AXON Neuroscience SE, Larnaca, \\ Cyprus
}

OPEN ACCESS

Edited by: Irving E. Vega,

Michigan State University,

United States

Reviewed by:

Naruhiko Sahara,

National Institute of Radiological

Sciences (NIRS), Japan

Katharina Schindowski Zimmermann,

Biberach University of Applied

Sciences, Germany

Isidre Ferrer

University of Barcelona, Spain

*Correspondence:

Michal Novak

michal.novak@savba.sk

Specialty section:

This article was submitted to

Neurodegeneration

a section of the journal

Frontiers in Neuroscience

Received: 02 August 2018

Accepted: 15 October 2018

Published: 02 November 2018

Citation:

Novak P, Kontsekova E, Zilka N and

Novak M (2018) Ten Years

of Tau-Targeted Immunotherapy:

The Path Walked and the Roads

Ahead. Front. Neurosci. 12:798.

doi: 10.3389/fnins.2018.00798
Neurofibrillary pathology comprised of pathological tau protein is closely tied to a range of neurodegenerative disorders, the most common of which is Alzheimer's disease. While they are individually rarer, a range of other disorders, the tauopathies (including Pick's disease, progressive supranuclear palsy, corticobasal degeneration, primary progressive aphasia, and $\sim 50 \%$ of behavioral variant frontotemporal dementia cases) display pronounced underlying tau pathology. In all cases, the distribution and amount of tau pathology closely correlates with the severity and phenotype of cognitive impairment, and with the pattern and degree of brain atrophy. Successfully counteracting tau pathology is likely to halt or slow the progression of these debilitating disorders. This makes tau a target of prime importance, yet an elusive one. The diversity of the tau proteome and post-translational modifications, as well as pathophysiology of tau are reviewed. Beginning 2013, a range of tau-targeted immunotherapies have entered clinical development; these therapies, and their common themes and differences are reviewed. The manuscript provides an extensive discussion on epitope selection for immunotherapies against tau pathology, on immunological mechanisms involved in their action, and challenges such as immune senescence, vaccine design, or evolution of epitopes. Furthermore, we provide methodological recommendations for the characterization of active vaccines and antibodies, animal models, and the target itself - the diseased tau proteome.

Keywords: tau, immunotherapy, neurofibrillary degeneration, clinical trials, animal models

\section{TAU PATHOLOGY IN A NUTSHELL}

In his seminal discovery, Alois Alzheimer has described two prominent changes in the brain of his patient - senile plaques composed of amyloid- $\beta$, and neurofibrillary pathology composed of protein tau (Alzheimer, 1907; Braak et al., 1994). The former received massive attention due to the simple fact that rare monogenic mutations in the amyloid precursor protein, or in the presenilins involved in its processing cause a neurodegenerative phenotype that is indistinguishable from 'sporadic' AD that makes up $>95 \%$ of $\mathrm{AD}$ cases (Blennow et al., 2006). The discovery that tau mutations are able to cause neurodegenerative disease on their own (Poorkaj et al., 1998) was vital to highlight the clinical relevance of tau pathology. Recent large-scale studies have revealed the close correlation between tau lesions and progression of neurodegenerative disease (Nelson et al., 2012; Murray et al., 2015). The disease phenotype reflects the distribution and severity 
of tau pathology in multiple tauopathies, including primary progressive aphasia, progressive supranuclear palsy, and corticobasal degeneration (Josephs et al., 2006). Analogously, tau PET imaging studies demonstrated that tau pathology is related in a region-specific manner to cognitive impairment in Alzheimer's disease subjects (Bejanin et al., 2017). Interestingly, tau pathology in the medial temporal lobe is associated with episodic memory performance and atrophy also in cognitively normal adults, independent of $\mathrm{A} \beta$ (Maass et al., 2018). Tau pathology is a condition sine qua non for Alzheimer's-type dementia, present in some form from the inception of the neurodegenerative process to its grim conclusion (Braak and Braak, 1991; Braak and Del Tredici, 2011); pure amyloidosis is asymptomatic (Murray et al., 2015). It is not far-fetched to expect that successfully counteracting the progression of tau pathology would delay the progression of $\mathrm{AD}$ as a whole, or halt it in its tracks if an efficacious intervention is applied early enough.

The main challenge in the study of tau pathology is the immense diversity of the pool of physiological and pathological tau molecules. Alternative splicing gives rise to six tau isoforms in the CNS; one of these (the inclusion of the optional microtubulebinding repeat coded by exon 10) is already highly relevant for tau pathology (Spillantini and Goedert, 2013). The picture is complicated by the $\sim 80$ possible phosphorylation sites on tau, and the lively interplay of kinases and phosphatases that alter tau's phosphorylation pattern (Grundke-Iqbal et al., 1986; Iqbal et al., 2016). A vast number of other possible post-translational modifications, such as truncation (Novak et al., 1993), nitration (Horiguchi et al., 2003), glycation (Ledesma et al., 1994), glycosylation (Wang et al., 1996), and ubiquitination (Mori et al., 1987) further expands the diversity of tau. Furthermore, the function of tau differs based on the molecule's location axonal (Méphon-Gaspard et al., 2016), dendritic (Ittner and Ittner, 2018), nuclear (Paholikova et al., 2014), or extraneuronal (Yamada et al., 2014; Sato et al., 2018). Finally, as an intrinsically disordered protein, tau behaves in a fundamentally different fashion when bound to interaction partners in contrast to being unbound in solution (Avila et al., 2016). These modifications create a pool of diverse tau molecules - the tau proteome. Different tau proteomes exists in health and disease. Thus, while "AD tau proteome" denotes the entire range of tau forms and derivatives present in Alzheimer's, the term "physiological tau proteome" denotes solely the range of tau forms present in a brain in the absence of tauopathy. The overlap of these proteomes is substantial. It is likely that the entirety of the healthy proteome continues to exist in disease (albeit changed in quantity), along with a vastly expanded diseased proteome. Still, the idea that certain tau moieties are lost in disease may be worth investigating.

The burden of post-translational modifications of tau protein causes the transition of tau from its highly soluble physiological form into insoluble aggregated pathological forms. Hyperphosphorylation (Arif et al., 2014), truncation (Zilka et al., 2012 b), or a combination of both are likely responsible, changing the disorder of tau into a mis-disordered pre-aggregation state, which then leads to fibril formation (Kovacech et al., 2010). The initiating factor behind these changes is unknown as of now, though it is likely that multiple endogenous and environmental factors lead to the formation of pathological tau naturally. Genetic (Lambert et al., 2013) and lifestyle factors (Baumgart et al., 2015) will determine the neurons' proteostatic capacity and general resilience against tauopathy, and the size of the burden. For example, psychological stress and stress-induced kinases were shown to increase the phosphorylation burden of tau (Rissman et al., 2012; Lopes et al., 2016). Once the combined burden exceeds the proteostatic capacity (Balch et al., 2008) of vulnerable neurons, the patient's brain begins its descent into tauopathy. Miniscule differences in the production or degradation of pathological tau can have a massive impact on its quantity (Gsponer et al., 2008), upsetting the status quo. Tau pathology results in a loss of physiological function and gain of toxic function. While in health, tau is vital to microtubule assembly (Weingarten et al., 1975), cellular transport (Klein et al., 2002), and DNA protection, diseased tau instead creates oligomers and fibrils (Wischik et al., 1988), destabilizes microtubules (Zilka et al., 2006), damages the proteasome (Opattova et al., 2013), causes neuronal and synaptic loss (Gómez-Isla et al., 1997; Tai et al., 2012) and promotes neuroinflammation (Zilka et al., 2012a). Seeding-capable tau molecules ("tauons") convert healthy tau into pathological forms, and propagate tau pathology from cell to cell via multiple pathways (Novak et al., 2011; Mudher et al., 2017). Tau pathology results in axonal destabilization and impairment of transport (Wang and Mandelkow, 2016). Cytoskeletal changes, rarefication of neuronal processes, axonal retraction, and finally neuronal death follow (Braak et al., 1994; Kanaan et al., 2013).

The diversity in pathological tau forms entails a similar diversity in tau lesion distribution, morphology, and composition (Sergeant et al., 2005; Fitzpatrick et al., 2017; Falcon et al., 2018) (see Table 1). The phenotype of $\mathrm{AD}$ and non-AD tauopathies aligns with the distribution of neurofibrillary lesions, and the severity of impairment is tied to the amount of tau pathology present (Dickson et al., 2011; Josephs et al., 2011; Nelson et al., 2012). Specifically in AD, the lesion spreading pattern inversely recapitulates the myelogenesis of the brain (Braak et al., 2006), hinting at a selective vulnerability of flexible, poorly myelinated neurons with limited perineuronal support nets (Morawski et al., 2010) to AD pathology. Patterns of vulnerability to other types of tau pathology likely influence the lesion distribution in other tauopathies. For example, brain regions predominantly affected by the $4 \mathrm{R}$-tauopathy PSP express a higher ratio of $4 \mathrm{R}$-tau even in healthy controls (Majounie et al., 2013).

Numerous less well known and less common disorders with tau lesions other than those mentioned in Table 1 exist, e.g., familial British dementia and familial Danish dementia (Vidal et al., 1999), Parkinsonism-dementia complex of Guam (Arif et al., 2014), and many others (Spillantini and Goedert, 2013).

To counteract tau pathology via immunotherapy, it is necessary to characterize the pathological tau proteome in the target disorder(s), find the proper epitope(s) that would allow the capture of pathological tau moieties en masse and in their entirety, and interfere in the propagation of tau pathology. The mechanisms of action being discussed by the field include inhibition of aggregation and dis-aggregation, opsonisation and phagocytosis, immobilization of tau seeds and uptake inhibition, 
TABLE 1 | Overview of the most prevalent tauopathies.

\begin{tabular}{|c|c|c|c|c|}
\hline Disease & Tau lesion type & Lesion distribution & Phenotype & Reference \\
\hline Alzheimer's disease & $\begin{array}{l}\text { Neurofibrillary tangles } \\
\text { Neuritic component of plaques } \\
\text { Neuropil threads } \\
\text { 3R+4R tau }\end{array}$ & $\begin{array}{l}\text { Allocortex, limbic regions, most } \\
\text { neocortical fields except motor } \\
\text { cortex, brainstem (locus } \\
\text { coeruleus, raphe nuclei) }\end{array}$ & $\begin{array}{l}\text { Predominantly amnestic, w. } \\
\text { disorientation in time and space. } \\
\text { Language, dysexecutive, and visual } \\
\text { variant exist. Multiple domains } \\
\text { impaired in dementia. }\end{array}$ & $\begin{array}{l}\text { Pathology: (Braak and Braak, } \\
\text { 1991) } \\
\text { Clinics: (Morris et al., 2014; Jack } \\
\text { et al., 2018) }\end{array}$ \\
\hline $\begin{array}{l}\text { Argyrophilic grain } \\
\text { disease }\end{array}$ & $\begin{array}{l}\text { Argyrophilic grains, } \\
\text { pre-neurofibrillary tangles in } \\
\text { neurons and coiled bodies in } \\
\text { oligodendrocytes } \\
\text { 4R tau }\end{array}$ & $\begin{array}{l}\text { Mainly entorhinal cortex and } \\
\text { hippocampus, insula, } \\
\text { amygdala, hypothalamus, } \\
\text { cingulated gyrus, ... }\end{array}$ & $\begin{array}{l}\text { Amnestic and multi-domain } \\
\text { cognitive impairment. Behavioral } \\
\text { abnormalities and FTD-like } \\
\text { symptoms possible. }\end{array}$ & $\begin{array}{l}\text { Pathology: (Grinberg and } \\
\text { Heinsen, 2009) } \\
\text { Clinics:(Rodriguez et al., 2016) }\end{array}$ \\
\hline $\begin{array}{l}\text { Chronic traumatic } \\
\text { encephalopathy }\end{array}$ & $\begin{array}{l}\text { Neurofibrillary tangles and } \\
\text { neurites, astrocytic tangles } \\
3 \mathrm{R}+4 \mathrm{R} \text { tau }\end{array}$ & $\begin{array}{l}\text { Focal (perivascular) epicenters, } \\
\text { amygdala, hippocampus, } \\
\text { nucleus basalis of Meynert, } \\
\text { substantia nigra, locus } \\
\text { coeruleus }\end{array}$ & $\begin{array}{l}\text { Mainly executive function, behavior, } \\
\text { and short-term memory impaired }\end{array}$ & $\begin{array}{l}\text { Pathology: (McKee et al., 2013) } \\
\text { Clinics: (McKee et al., 2013) }\end{array}$ \\
\hline $\begin{array}{l}\text { Corticobasal } \\
\text { degeneration }\end{array}$ & $\begin{array}{l}\text { Pre-tangles } \\
\text { Astrocytic plaques thread-like } \\
\text { lesions, corticobasal bodies, } \\
\text { and coiled bodies 4R tau }\end{array}$ & $\begin{array}{l}\text { Basal ganglia, thalamus, focal } \\
\text { parietal, mostly asymmetric, } \\
\text { and brainstem }\end{array}$ & $\begin{array}{l}\text { Asymmetric levodopa-resistant } \\
\text { parkinsonism, postural instability, } \\
\text { dystonia, myoclonus. Behavioral } \\
\text { changes, aphasia, cognitive } \\
\text { impairment. Cortical sensory loss. } \\
\text { Alien limb. }\end{array}$ & $\begin{array}{l}\text { Pathology: (Josephs et al., 2011) } \\
\text { Clinics: (Armstrong et al., 2013; } \\
\text { Levin et al., 2016) }\end{array}$ \\
\hline $\begin{array}{l}\text { Dementia in Down } \\
\text { syndrome }\end{array}$ & Similar to AD & Similar to AD & $\begin{array}{l}\text { Similar to AD, complicated by } \\
\text { existing cognitive disability }\end{array}$ & $\begin{array}{l}\text { Pathology: (Hof et al., 1995) } \\
\text { Clinics: (Ghezzo et al., 2014) }\end{array}$ \\
\hline $\begin{array}{l}\text { Frontotemporal lobar } \\
\text { degeneration (w./w.o. } \\
\text { Parkinsonism) }\end{array}$ & $\begin{array}{l}\text { (extremely varied) } \\
3 \mathrm{R}, 4 \mathrm{R}, \text { or } 3 \mathrm{R}+4 \mathrm{R} \text { tau }\end{array}$ & $\begin{array}{l}\text { Frontal and } \\
\text { temporal/temporoparietal } \\
\text { neocortex, (substantia nigra) }\end{array}$ & $\begin{array}{l}\text { Language (PPA), behavior, } \\
\text { executive function (bvFTD), possibly } \\
\text { parkinsonism (FTDP-17) }\end{array}$ & $\begin{array}{l}\text { Pathology: (Seilhean et al., 2011) } \\
\text { Clinics: (Wszolek et al., 2006; } \\
\text { Gorno-Tempini et al., 2011) }\end{array}$ \\
\hline Pick's disease & $\begin{array}{l}\text { Pick bodies } \\
\text { Astroglial processes } \\
\text { 3R tau }\end{array}$ & $\begin{array}{l}\text { Frontal and temporal } \\
\text { neocortex, dentate gyrus, deep } \\
\text { gray matter and brainstem } \\
\text { (monoaminergic nuclei) }\end{array}$ & $\begin{array}{l}\text { Language, behavior, executive } \\
\text { function (as bvFTD or PPA) }\end{array}$ & $\begin{array}{l}\text { Pathology: (Sieben et al., 2012) } \\
\text { Clinics: (Hodges et al., 2004; } \\
\text { Warren et al., 2013) }\end{array}$ \\
\hline $\begin{array}{l}\text { Progressive } \\
\text { supranuclear palsy }\end{array}$ & $\begin{array}{l}\text { Globose NFTs } \\
\text { Tufted astrocytes } \\
4 \mathrm{R} \text { tau }\end{array}$ & $\begin{array}{l}\text { Predominantly in basal ganglia, } \\
\text { subthalamic nucleus, and } \\
\text { substantia nigra. Involvement of } \\
\text { motor cortex and cerebellum } \\
\text { (e.g., superior cerebellar } \\
\text { peduncle). }\end{array}$ & $\begin{array}{l}\text { Vertical supranuclear gaze palsy, } \\
\text { postural } \\
\text { instability, falls, pseudobulbar palsy, } \\
\text { rigidity, akinesia; behavior, executive } \\
\text { function, and language impaired; } \\
\text { Parkinsonism }\end{array}$ & $\begin{array}{l}\text { Pathology: (Josephs et al., 2011) } \\
\text { Clinics: (Levin et al., 2016; } \\
\text { Respondek and Hoglinger, 2016) }\end{array}$ \\
\hline Tangle-only dementia & $\begin{array}{l}\text { Neurofibrillary tangles } \\
\text { Neuropil threads } \\
\text { Ghost tangles } \\
3 R+4 R \text { tau } \\
4 R \rightarrow 3 R \text { shift during tangle } \\
\text { maturation }\end{array}$ & $\begin{array}{l}\text { Allocortex and medial temporal } \\
\text { lobe, limbic regions; } \\
\text { subcortical: locus coeruleus, } \\
\text { nucleus basalis of Meynert, } \\
\text { amygdala }\end{array}$ & $\begin{array}{l}\text { Mainly memory deficit; slower } \\
\text { progression than } A D\end{array}$ & $\begin{array}{l}\text { Pathology and Clinics: (Jellinger } \\
\text { and Bancher, 1998; Jellinger and } \\
\text { Attems, 2007) }\end{array}$ \\
\hline
\end{tabular}

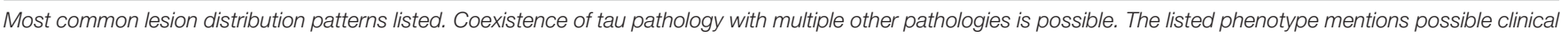
manifestations; not all signs are required for diagnosis. Lesser amounts of $3 R$-tau can be found in $4 R$-tau dominated pathologies, and vice versa.

binding-mediated conformational change, tau re-distribution, and overall tau reduction.

\section{EPITOPE SELECTION}

Due to the flexibility of the tau molecule, and due to the plethora of post-translational modifications that occur in health and in disease, the epitope landscape of tau is exceedingly rich. Not every epitope appearing on pathological tau is a viable immunotherapy target, though. Obviously, epitopes that predominantly appear on pathological tau, or are better accessible in pathological tau molecules than in their healthy counterparts should be preferred, as opposed to indiscriminately removing any tau. Reducing healthy tau protein was found to have detrimental effects (Marciniak et al., 2017), and (presumably) diluting the effect of the antibody between healthy (irrelevant) and pathological tau forms could reduce the overall efficacy of the treatment.

It is well known that truncation of tau's $\mathrm{N}$ - and C-terminus promotes the molecule's transition from its healthy state into pathological forms (Zilka et al., 2012b). Tau aggregation 
occurs inevitably via the microtubule binding region (MTBR) (Fitzpatrick et al., 2017), and in line with this mechanism, the only part of tau that is retained in all tau molecules that constitute and propagate neurofibrillary pathology is the MTBR. Conspicuously, tau fragments in the CSF of AD patients meanwhile rarely if ever contain the MTBR (Sato et al., 2018). Under physiological conditions, tau in the extracellular space in the brain is either full-length or truncated at the C-terminus. It is highly possible that tau containing MTBR is rapidly degraded in order to prevent formation of tau oligomers. Phosphorylation can speed up the process of tau degradation suggesting its physiological role in tau turnover (Sato et al., 2018). On the other hand, one or both termini of tau are absent in an important subset of pathological tau forms in the $\mathrm{AD}$ brain (Zilka et al., 2012b; Zhou et al., 2018), which thus escape immunotherapies aimed at epitopes on termini. The fact that tau becomes progressively more truncated (e.g., first at Asp421, then at Glu391) (Binder et al., 2005) illustrates that there may be a similar limitation to immunotherapies aimed at these new termini.

Other post-translational modifications of tau protein are similarly potential targets - whether phosphorylation, ubiquitination, glycation, glycosylation, or nitration, they all create novel epitopes on tau. The main limitation here is that many of these modifications are subject to a large degree of fluctuation. The main challenge is characterizing their distribution across the pool of all pathological tau moieties over the course of the disorder.

Conformation is an often-overlooked aspect of tau pathology (Novak et al., 2018b). Some epitopes may arise purely due to the alteration of the molecule's conformation, and accessibility of individual epitopes may differ based on the binding partners, current conformation, and aggregation status of tau.

Location of the targeted tau moieties is also a crucial aspect. It is evident that intracellular and extracellular tau, and the tau molecules that pass into the CSF differ. In comparison to immunotherapies targeting extracellular pathology, such as $A \beta$, tau-targeted immunotherapy faces an additional challenge: many types of tau are located intracellularly [whether axonal, dendritic (Ittner and Ittner, 2018), somatic, or nuclear (Paholikova et al., 2014)]. The opinions differ on whether the intracellular compartments are accessible to immunotherapy, though. Tau responsible for intercellular spread has to pass through extracellular space, where it is accessible to immunotherapy (Evans et al., 2018) - unless it utilizes solely tunneling nanotubes. Also, we suspect that neurons outsource a portion of tau to their supporting cells for processing (Morawski et al., 2010; Mohamed et al., 2014); this tau could also be targeted in the extracellular space.

Finally, there is a subset of epitopes that are truly unsuited as immunotherapy targets. Antibodies binding to these epitopes were shown to promote tau aggregation in vitro (Kontsekova et al., 2014b). The promotion of tau aggregation occurred also in cell-free solution; thus, the most likely explanation is that antibodies against certain tau epitopes serve to stabilize a pathological tau conformation that promotes further aggregation.

Summarily, the presence of an epitope on pathological tau is not sufficient to make it a good immunotherapy target. It is necessary to know what the function of individual (pathological) epitopes is, what targeting a certain epitope means for the tau molecule, and what downstream mechanisms are engaged after antibody binding.

A range of assays can serve to evaluate the properties of candidate antibodies. It is not sufficient to demonstrate the antibody's affinity to tau constructs or extracts in ELISA or similar methods. Ideally, for comparability purposes, it should be shown which parts of the tau proteome the antibody targets (e.g., both low molecular weight fragments, and higher molecular weight oligomers and fibrils). A range of seeding and aggregation assays can inform about the impact of immunotherapy on tau aggregation and fibrillisation. If an antibody is intended to opsonise tau for removal by the immune system, then its performance in phagocytosis promotion assays (e.g., assessed by flow cytometry) should be adequate. Microtubule assembly assays can be used to evaluate whether the antibody inhibits the cytoskeletondestabilizing properties of pathological tau. Various seeding and tau spreading assays can be utilized to evaluate the antibody's capability to halt the spread of tauons (Nobuhara et al., 2017).

\section{CHARACTERIZATION OF THERAPEUTICS AND MODELS}

In recent years, the number of publications on the role of tau protein in neurodegenerative disease, its (patho)physiology, and its role in diagnosis has skyrocketed - but often, the comparability of studies remains low. For the tau field to move forward in a consistent fashion, certain standards of methodology need to be established.

Comparability of immune response between studies (preclinical, clinical) is very low due to poor reporting standards for immunological outcomes (Agadjanyan et al., 2015). For active immunotherapies, the reporting of titre should

TABLE 2 | Proposed substrates for reactivity assessments of tau-targeted immunotherapies.

\begin{tabular}{ll}
\hline Substrate & Description and details \\
\hline The immunogen & Reference substrate \\
\hline Healthy tau protein & $\begin{array}{l}\text { Physiological tau, ideally both 3R and 4R (e.g., } \\
\text { 2N3R, 2N4R) }\end{array}$ \\
\hline Post-translationally modified tau & Truncated tau species, phospho-species \\
\hline Sarcosyl-insoluble tau & $\begin{array}{l}\text { Qualitative assessment in Western blot, } \\
\text { quantitative assessment in ELISA, comparison } \\
\text { to pan-tau antibody }\end{array}$ \\
\hline
\end{tabular}

Human brain tissue Tissue immunohistochemistry on AD and non-AD tauopathies 
be standard - using arbitrary ELISA units obscures the true antibody response, and makes comparisons all but impossible. Absolute quantification of antibody amount per volume would be ideal, as methodological issues (e.g., chromogen, secondary antibody) can confound titre measurements. Furthermore, for antibodies elicited in patients by the immunotherapy, the reactivity with various substrates needs to be evaluated thoroughly. Similarly, for passive vaccines, what the antibody targets and what it does not should be made perfectly clear (Table 2).

For all tau-targeted therapies, what should be established is a comparability of models. Authors generally speak of models 'developing tau pathology' and the tau pathology being treated by their compound of choice. The average AT8-positive clump in a cell tells little about the nature of tau pathology in a given model, and its relevance to human disease. Models currently employed by the field are exceedingly diverse, differing in transgene (almost exclusively various forms of mutated tau), genetic background (multiple crossings of various mouse lines generating extensive variability of the phenotype), and expression level (related to the promotor), and thus it is not surprising that the resulting pathology differs as well (Skrabana et al., 2017). For example, numerous models don't develop sarcosyl-insoluble tau, or higher order aggregates; argyrophilia or thioflavin-S reactivity is frequently absent. In other models, the transgene lacks the ability to sequester endogenous rodent tau. Models based on seeding tau pathology with exogenous material sometimes use recombinant tau fibrils, but human tauon strains are best replicated by utilizing genuine brain homogenates from human disease (Guo et al., 2016). While sequence homology between human and rodent tau is high, there are important differences in sequence and function, which may impact whether particular disease mechanisms can be modeled in rodents at all (Hernandez et al., 2018). The questions are obvious. How predictive are models with little tau aggregation for antibodies that aim to stop tau aggregation in human disease? How predictive are models that lack $\beta$-sheet structure in tau for therapies that aim to target human tau pathology that is arranged in $\beta$-sheets (Fitzpatrick et al., 2017)? Do we sufficiently account for the fact that a large portion of animal models of tau pathology is based on mutant tau, whereas most human tauopathy cases and all AD cases are not caused by a tau mutation? Finally, few authors investigate the impact that genetic background of the transgenic animals can have on the effects

TABLE 3 | Proposed aspects of model characterization.

\begin{tabular}{|c|c|c|c|}
\hline & Model attribute & Method & Reference \\
\hline \multirow[t]{6}{*}{ Biochemical aspects } & Tau proteome & $\begin{array}{l}\text { Western blot } \\
\text { - Sarcosyl-insoluble extracts } \\
\text { - Antibodies specific for post-translational modifications } \\
\text { - Antibodies specific for endogenous and transgenic/injected tau }\end{array}$ & $\begin{array}{l}\text { Zilka et al., 2006; Yu et al., 2009; Forest } \\
\text { et al., } 2013\end{array}$ \\
\hline & Filament morphology & Electron microscopy & $\begin{array}{l}\text { Crowther and Goedert, } \\
\text { 2000;Ksiezak-Reding and Wall, 2005; } \\
\text { von Bergen et al., } 2006\end{array}$ \\
\hline & $\begin{array}{l}\text { Pathology distribution } \\
\text { and morphology }\end{array}$ & $\begin{array}{l}\text { Immunohistochemistry } \\
\text { - Antibodies specific for post-translational modifications } \\
\text { - Antibodies specific for endogenous and transgenic/injected tau }\end{array}$ & $\begin{array}{l}\text { Braak and Braak, 1991; Zilka et al., } \\
\text { 2006; Josephs et al., } 2011\end{array}$ \\
\hline & Presence of $\beta$-sheets & Staining with Thioflavin-S, Congo-red, silver & Vallet et al., 1992 \\
\hline & Seeding capability & In vitro (solution, cell assays) and in vivo (stereotaxic) seeding & $\begin{array}{l}\text { Audouard et al., 2016; Courade et al., } \\
2018\end{array}$ \\
\hline & $\begin{array}{l}\text { Transgene expression } \\
\text { level }\end{array}$ & $\begin{array}{l}\text { Quantitative real time PCR (mRNA), Western blot, ELISA (protein), both } \\
\text { related to the expression of endogenous tau }\end{array}$ & Koson et al., 2008; Filipcik et al., 2012 \\
\hline \multirow[t]{2}{*}{ Clinical aspects } & Impairment phenotype & Cognitive and motor assays, EEG, electrophysiology & $\begin{array}{l}\text { Webster et al., 2014; Menkes-Caspi } \\
\text { et al., 2015; Wolf et al., } 2016\end{array}$ \\
\hline & Age of onset, survival & - & Stel et al., 2011 \\
\hline \multirow[t]{4}{*}{ Other } & Variability & $\begin{array}{l}\text { Numerical variability in all of the above aspects must be quantified, with } \\
\text { special attention to the effects of sex and genetic background. }\end{array}$ & - \\
\hline & Neuronal loss & Quantification of neuron specific markers & West et al., 1991 \\
\hline & Synaptic loss & Quantification of synaptic markers & Robinson et al., 2014 \\
\hline & Neuroinflammation & Activation of astrocytes and microglia, cytokine profile & $\begin{array}{l}\text { Stozicka et al., 2010; Kovac et al., } \\
\text { 2011; Zilka et al., 2012a; Heneka et al., } \\
\text { 2015; }\end{array}$ \\
\hline
\end{tabular}


of a transgene; these effects can be pronounced (Stozicka et al., 2010).

To evaluate the properties of a model, and judge its suitability for preclinical efficacy assessment of tau-targeted immunotherapies, at least the features in Table 3 should be reported.

Beside the attributes outlined in Table 3, certain additional aspects should be reported about specific types of models. For models designed utilizing viral vectors (e.g., Bolognin et al., 2012), an eventual impact of the vector itself should be analyzed and reported. The type, percentage, and distribution of transfected cells, as well as persistence of transfection should be evaluated. For models based on the administration of seeding-capable tau protein (e.g., Clavaguera et al., 2009; Guo et al., 2016), the seed should be thoroughly biochemically characterized, and the resulting tau pathology compared to it. Any methods used to 'pre-condition' the recipient animal (such as a transgenic background expression of human tau) should be reported; ideally, the impact of said pre-conditioning should be evaluated by comparing the results to the same procedure in wild-type animals. For models that develop pathology due to their transgene alone, the additional impact of administration of seeding-capable tau can be difficult to evaluate. On the contrary, when using models where expression of diseased tau is widespread, the researcher will have to address whether and how spreading mechanisms can be evaluated in this type of animal.

\section{IMMUNOTHERAPIES IN CLINICAL DEVELOPMENT}

\section{Epitope Selection}

Close to a dozen tau-targeted immunotherapies have been advanced to clinical trials since the debut of AADvac1 in 2013 (Kontsekova et al., 2014a). Differences in design philosophy of these immunotherapies are evident.

The active AADvac1 vaccine induces specific antibodies targeting 3 or 4 conformational epitopes on mis-disordered tau protein with an exposed microtubule-binding repeat domain, such as appear on truncated, oligomeric, and aggregated $3 R / 4 R$ tau. The antibodies raised by the vaccine preferentially target the pathological forms of tau (Kontsekova et al., 2014a,b, Novak et al., 2017). Targeting of the four epitopes located throughout the microtubule-binding region is advantageous, as all aggregation of tau occurs via this domain (Fitzpatrick et al., 2017), and by targeting it, antibodies elicited by the vaccine are likely to both inhibit further aggregation, and capture all aggregation-capable tau species.

The recently unveiled monoclonal antibody UCB0107 also focuses on the central region of tau protein (residues 235-246 in close proximity of the microtubule-binding region), with a similar primary goal of inhibiting seeding-capable tauons, and thus preventing the spread of neurofibrillary pathology ${ }^{1}$.

Similarly, the monoclonal antibody LY3303560 derived from the MC-1 antibody (Jicha et al., 1997), reactive with aa313-322

${ }^{1}$ www.alzforum.org of the third repeat domain, but also dependent on the aa 7-9 of tau's N-terminus for binding, is being clinically developed. The antibody's more extensive binding site in the repeat region is close to the ${ }^{306}$ VQIVYK $^{311} \beta$-sheet forming motif (von Bergen et al., 2006) which is flanked from the other side by the AADvac1-targeted epitope ${ }^{294}$ KDNIKHVPGGGS $^{305}$. Therefore, the mechanisms of action of LY3303560 and AADvac1induced antibodies may have commonalities, e.g., affecting the aggregation of tau, and capturing tauons which inevitably have this domain, though LY3303560 will miss any N-terminally truncated tau species (Courade et al., 2018).

The C-terminus of the molecule, particularly the serine residues S396/S404 that become differentially phosphorylated especially in pathological tau, were chosen as the target for the active vaccine ACI-35 (Theunis et al., 2013). In their later work, the authors reveal that the induced antibody response mainly recognizes the pS396 epitope, along with conformational change as factors distinguishing between healthy and pathological tau protein (Theunis et al., 2017). It is uncertain whether antibodies recognizing pS396 alone target the same (or similar) pool of tau as recognized by the PHF1 antibody, though.

Both AADvac1 and ACI-35 focus strongly on the selectivity of the antibodies for pathological tau. In combination with the over-abundance of pathological tau over physiological tau in the $\mathrm{AD} /$ tauopathy brain, and considering the fact that pathological tau will be over-represented in the extracellular space, off-target reactivity against healthy tau will be greatly reduced. Not all tau-targeted immunotherapies focus as much on this property, with some being content to target any extracellular tau.

The monoclonal IgG1 antibody BIIB076 (Czerkovicz et al., 2018) is classified as a pan-tau antibody and is reported to target monomeric and fibrillary forms of tau pathology, without regard to whether they are specific for $\mathrm{AD}$.

ABBV 8E12 targets aa25-30 at the N-terminus of tau with the aim to clear extracellular forms, and thus inhibit seeding (West et al., 2017). Another monoclonal antibody targeted at the $\mathrm{N}$-terminus, the IgG4 antibody BIIB092, focuses on N-terminal fragments of tau (which likely arise during tau truncation) with the aim of reducing their secondary impact on amyloid- $\beta$ processing and pathology, and countering neuronal hyperactivity (Bright et al., 2015); the antibodies are thus bound to miss any N-terminally truncated tauons, though. Similarly, the RO 7105705 antibody aims at the $\mathrm{N}$-terminus of extracellular tau, and does not place importance on discrimination between tau forms specific to $\mathrm{AD} /$ tauopathy and those observed in healthy brains.

The jury is still out on whether tau-targeted antibodies actually are able to enter neurons or not. One group reports this is the case (Gu et al., 2013), while numerous others don't report any passage of antibodies into neurons. In our in-house studies, no passage of tau-targeted antibodies into intact neurons was observed as of today. The final answer to this question is especially relevant for tau-targeted immunotherapies that don't preferentially target diseased tau, as undesired interference with interneuronal transfer of non-pathogenic tau may have profound consequences (Bright et al., 2015; Evans et al., 2018).

Along with an understanding of the function of tau's domains in health and disease comes the realization that it is likely not 
TABLE 4 | Overview of tau-targeted immunotherapies in clinical development.

\begin{tabular}{|c|c|c|c|c|c|}
\hline Compound & Type and isotype & Epitope & Targeted tau species & Proposed mechanism & Disease models used \\
\hline AADvac1 & $\begin{array}{l}\text { Active, antibody response } \\
\text { is mostly lgG1 }\end{array}$ & $\begin{array}{l}\text { Primary: 294-305 } \\
\text { Secondary: 268-283; } \\
\text { 330-335; 362-367 }\end{array}$ & $\begin{array}{l}\text { Conformationally altered } \\
\text { extracellular tau (monomer, } \\
\text { oligomer, fibril), focusing on } \\
\text { seeding-capable } \\
\text { extracellular tau }\end{array}$ & $\begin{array}{l}\text { Anti-aggregation, } \\
\text { opsonisation, inhibition of } \\
\text { cell-to-cell spread of } \\
\text { neurofibrillary pathology } \\
\text { Ref.: (Kontsekova et al., } \\
\text { 2014a,Kontsekova et al., } \\
\text { 2014b; Novak et al., 2017) }\end{array}$ & $\begin{array}{l}\text { SHR72 rats (tau } \\
\text { 151-391/4R), SHR } \\
\text { background R3/m4 mice } \\
\text { (tau 151-391/34R), } \\
\text { C57BL/6 background }\end{array}$ \\
\hline $\mathrm{ACl}-35$ & Active & $\begin{array}{l}\text { pS396 (some sources } \\
\text { additionally mention pS404) }\end{array}$ & $\begin{array}{l}\text { Tau pS396 with a } \\
\text { conformation that is } \\
\text { typically present in the brain } \\
\text { of tauopathy patients, } \\
\text { preferentially multimeric } \\
\text { conformers }\end{array}$ & $\begin{array}{l}\text { Reduction of pS396-tau } \\
\text { (soluble and insoluble) Ref.: } \\
\text { (Theunis et al., 2013) }\end{array}$ & $\begin{array}{l}\text { P301L tau mice, } \\
\text { FVB/Nbackground }\end{array}$ \\
\hline ABBV-8E12 & Passive, IgG4 & $25-30$ & Extracellular tau & $\begin{array}{l}\text { Inhibition of cell-to-cell } \\
\text { spread of neurofibrillary } \\
\text { pathology Ref.: } \\
\text { (Yanamandra et al., 2015) }\end{array}$ & $\begin{array}{l}\text { P301S tau mice, B6C3 } \\
\text { background }\end{array}$ \\
\hline BIIB076 & Passive, IgG1 & Undisclosed & $\begin{array}{l}\text { Monomeric and fibrillary } \\
\text { forms, as well as tau } \\
\text { isolated from healthy } \\
\text { human and Alzheimer's } \\
\text { disease brains. }\end{array}$ & $\begin{array}{l}\text { (undisclosed) Ref: } \\
\text { alzforum.org }\end{array}$ & (Undisclosed) \\
\hline BIIB092 & Passive, IgG4 & $\begin{array}{l}\text { Exact epitope undisclosed } \\
\text { (N-terminal inserts?) }\end{array}$ & $\begin{array}{l}\text { extracellular, N-terminal } \\
\text { fragments of tau (eTau) }\end{array}$ & $\begin{array}{l}\text { Secondary reduction of } \\
\text { amyloid- } \beta \text { and of neuronal } \\
\text { hyperactivity Ref: } \\
\text { alzforum.org }\end{array}$ & $\begin{array}{l}\text { JNPL3 P301L mice, } \\
\text { C57BL/DBA2/SW } \\
\text { background } \\
\text { tau-4R/2N-P301L van } \\
\text { Leuven mice, C57BI/6 } \\
\text { background }\end{array}$ \\
\hline JNJ-63733657 & $\begin{array}{l}\text { Passive, isotype } \\
\text { undisclosed }\end{array}$ & $\begin{array}{l}\text { Undisclosed, presumably } \\
\text { mid-region }\end{array}$ & Seeding-capable tau & $\begin{array}{l}\text { Neutralization of tau seeds } \\
\text { and reduction of pathology } \\
\text { Ref: alzforum.org }\end{array}$ & (Undisclosed) \\
\hline LY3303560 & $\begin{array}{l}\text { Passive, isotype } \\
\text { undisclosed }\end{array}$ & $7-9 ; 313-322$ & $\begin{array}{l}\text { Soluble tau aggregates with } \\
\text { intact } \mathrm{N} \text {-terminus }\end{array}$ & $\begin{array}{l}\text { Neutralization of tau seeds } \\
\text { and reduction of pathology. } \\
\text { Ref: alzforum.org }\end{array}$ & (Undisclosed) \\
\hline RO 7105705 & Passive, IgG4 & N-terminus & $\begin{array}{l}\mathrm{N} \text {-terminus of all six } \\
\text { isoforms, both monomeric } \\
\text { and oligomeric, regardless } \\
\text { of phosphorylation status }\end{array}$ & $\begin{array}{l}\text { Inhibition of cell-to-cell } \\
\text { spread of neurofibrillary } \\
\text { pathology Ref: alzforum.org }\end{array}$ & (Undisclosed) \\
\hline UCB0107 & $\begin{array}{l}\text { Passive, isotype } \\
\text { undisclosed }\end{array}$ & $235-246$ & $\begin{array}{l}\text { Seeding-capable } \\
\text { extracellular tau }\end{array}$ & $\begin{array}{l}\text { Inhibition of cell-to-cell } \\
\text { spread of neurofibrillary } \\
\text { pathology Ref: (Courade } \\
\text { et al., 2018), alzforum.org }\end{array}$ & (Undisclosed) \\
\hline
\end{tabular}

Epitopes numbered according to the 2N4R tau isoform.

sufficient to target any epitope on tau to have an impact on the progression of neurofibrillary pathology. The abovementioned immunotherapies will target different pools of tau, with different effects on the molecule upon antibody binding. Similarly, due to their differing isotypes, the downstream effects of antibody binding to tau will also differ.

\section{Isotype Selection}

Human IgG isotypes differ pronouncedly in their functions, especially in the downstream effects they initiate after binding, but also in their avidity and propensity to generate immune complexes. Especially some IgG subclasses (IgG1, IgG3) are adept at engaging downstream innate mechanisms, such as complement and phagocytosis by microglia (Vidarsson et al., 2014). Based on very limited evidence (Lee et al., 2016), a portion of the $\mathrm{AD}$ immunotherapy field seems to be laboring under the impression that engaging the innate immune system is inherently and invariably dangerous, and thus gravitates toward using IgG4 and modified backbones with reduced effector functions for their antibodies (Table 4). Extrapolating from in vitro isolated microglial culture from young rodents to elderly humans whose microglia are embedded in a complex network of 
interaction with other cells seems is unjustifiable though. They are fundamentally different entities (Smith and Dragunow, 2014); microglia that produce neurotoxic inflammatory mediators in culture may behave in a different manner in the living brain. It is indeed likely that microglial senescence and the ensuing reduced capacity of microglia to support neurons and phagocyte tauons are permissive factors involved in the pathogenesis of AD (Streit et al., 2009). Microglia probably are victims of the neurodegenerative process who actually need aid (e.g., in the form of tau-targeting antibodies) to properly oppose the progression of $\mathrm{AD}$. We believe that the microglia can be an extremely valuable ally in combating neurofibrillary pathology, if they are engaged properly (Novak et al., 2018b). The benign safety profile observed in studies of AADvac1 (Novak et al., 2017) (which induces an IgG1-dominated antibody response) indicates that pathological tau can be targeted safely with IgG1 antibodies.

It is essential to clarify whether it is sufficient to bind the targeted tau moiety via a monoclonal or vaccine-induced antibody, or whether downstream mechanisms such as Fc-receptor mediated phagocytosis are necessary for (or greatly contribute to) efficacy. While all monoclonal antibodies currently in clinical development are of the IgG1 or IgG4 isotypes, a case is to be made also for IgG3, whose greater flexibility of the Fab arms may promote avidity and antigen-binding capacity (Vidarsson et al., 2014). As a trade-off, this isotype promotes complement activation the most; should this trait be undesirable, there are ways to mitigate it (Saxena and $\mathrm{Wu}, 2016$ ). As for IgG4, one fact which must be kept in mind is that monovalent bispecific antibodies will result from the IgG4 Fab arm exchange (Schuurman et al., 1999), consisting of one light and one heavy chain of a random endogenous IgG4 antibody, and one half of the administered IgG4 monoclonal. These antibodies are unable to crosslink the same antigen - a property which may become important in the inhibition of tauons.

\section{Mechanisms of Action}

Generally, reports of tau-targeted immunotherapies focus on evaluating clinical and biochemical endpoints in animals and humans (test performance, biomarkers, atrophy, tau load and neurofibrillary tangle counts), and assessments of mechanism of action are relegated to in vitro assays.

The current understanding of the propagation of tau pathology highlights possible avenues by which an immunotherapy could intervene. At first, pre-aggregate forms of pathological tau are generated intracellularly. To target this step, antibodies would have to be able to enter neurons - this may or may not be possible. Once intracellular pathology is sufficiently advanced, the affected neuron begins to shed tau seeds the tauons (Mudher et al., 2017). Being (likely) extracellular (Novak et al., 2011), they are well-accessible to immunotherapy. Antibodies may be able to simply immobilize them by binding; disassembly of existing early-stage aggregates is also conceivable if the antibody is a more preferable binding partner for pathological tau than other tau molecules (Kontsekova et al., 2014b). The pathological conformation of tau molecules may be changed as antibodies bind them (another form of templatemediated conformational change, with the antibody acting as template/chaperone) (Sarkar et al., 2008). Via their effector functions, antibodies are able to engage immune cells, such as microglia, to phagocyte and degrade pathological tau (Bournazos et al., 2015). Antibodies may protect cells by preventing the binding of tauons to receptors that are needed for internalization (Evans et al., 2018). Finally (again, only if antibodies are able to enter neurons), template-mediated aggregation induced by tauons entering healthy neurons could be prevented via an antibody obstructing the aggregation process (Kontsekova et al., 2014b).

We have recently reported the proposed mechanism of AADvac1 (Novak et al., 2018b). In line with the above considerations, the goal of AADvac1 treatment is to induce antibodies that block the spread of tauopathy by immobilizing tauons and opsonising them for removal by the immune system, e.g., microglia. Mechanisms of other tau-targeted immunotherapies in clinical development are detailed in Table 4.

\section{Results of Animal Studies}

Where reported, the results of preclinical animal studies of the immunotherapies in Table 4 showed that the animal model of choice was treated with the compound, whereupon its tau pathology was reduced, and clinical symptoms improved. The significance of these findings is mostly determined by the validity of the treated animal model. The details of these results warrant further analysis, though.

Treatment of SHR72 transgenic rats with AADvac1 resulted in $\sim 70 \%$ less insoluble tau accumulation in their brains; interestingly, the amount of pathologically hyperphosphorylated tau was reduced by $90-98 \%$ (Kontsekova et al., 2014a). While the conformational epitope targeted by AADvac1 is phosphorylation-independent, the pronounced reduction in pathological phospho-tau species may indicate that conformationally altered tau is more liable to be hyperphosphorylated. The antibody response in the treated animals preferentially targeted pathological tau 151-391/4R, in comparison to physiological tau $2 \mathrm{~N} 4 \mathrm{R}$, and was able to recognize tau pathology in all evaluated Alzheimer brains (Kontsekova et al., 2014a). Both of the above were replicated in humans (Novak et al., 2017, 2018a). The administration route was identical in animals and humans (subcutaneous injection). Transgenic animals received five doses of $100 \mu \mathrm{g}$ peptide-KLH conjugate, with $\sim 16 \mu \mathrm{g}$ tau peptide per dose. Humans received a higher dose in the first-in-man study ( $40 \mu \mathrm{g}$ peptide coupled to KLH). Treatment alleviated approximately $50 \%$ of the animals' impairment, as measured by the Neuroscale test battery (Korenova et al., 2009; Kontsekova et al., 2014a).

Animal studies of ACI-35 included the evaluation of safety, immunogenicity, and efficacy in Tau.P301L mice. Following subcutaneous administration, the elicited antibodies recognized tau pathology in aged GSK3bxTauP301L mice; whether the antibodies are able to bind human tau pathology was not evaluated in the initial study (Theunis et al., 2013). The authors' later work indicates that the monoclonal antibody generated using ACI-35 recognizes human NFTs (Theunis et al., 2017). 
The evaluated safety parameters, e.g., T-cell response, gliosis, and various other inflammatory markers did not indicate any undesired activity of the immune system. Animals received a total of four doses; the exact tau peptide dose is not discernible from the manuscripts (Theunis et al., 2013). The treatment resulted in a $\sim 25 \%$ reduction of soluble pS396 phospho-tau, and a $\sim 33 \%$ reduction of sarcosyl-insoluble pS396 phospho-tau. Curiously, even though the immunogen also featured the pS404 phosphoepitope, the pS404 phospho-tau levels were not markedly affected by ACI-35 treatment; neither was insoluble pS396 phospho-tau in the brainstem. Modest clinical improvement was seen on hind-limb clasping, body weight, and survival (Theunis et al., 2013).

Weekly treatment of P301S mice with $50 \mathrm{mg} / \mathrm{kg}$ of the HJ8.5 antibody administered intraperitoneally over the course of 12 weeks resulted in pronounced reduction of formic acid soluble tau. Phospho-tau, as measured by the anti-pS202/pT205 antibody AT8, and thioflavin-S reactive pathology were affected as well. As P301S mice also suffer brain atrophy, the capacity of HJ8.5 to prevent this was assessed; the treatment resulted in a modest atrophy reduction. Improvements in sensorimotor function were also seen (Yanamandra et al., 2015). The humanized version of this antibody is in clinical trials under the name ABBV-8E12.

Differences in models and assessment methodology preclude direct efficacy comparisons of the above treatments, highlighting the need to establish assay and reporting standards. No publications on preclinical efficacy of the remaining compounds mentioned in Table 4 are available as of today.

\section{Results of Human Clinical Trials}

All tau-targeted immunotherapies in clinical trials are at early stages of development. Only limited clinical trial data have been reported so far, and only for AADvac1 (Novak et al., 2017, 2018a).

Treatment with AADvac1 was able to elicit an IgG response against the tau peptide in 29/30 treated patients, and a response against truncated tau 151-391/4R in 25 of 28 patients where this response was assessed (Novak et al., 2017). More importantly, the elicited antibodies were able to stain sarcosyl-insoluble tau extracts from Alzheimer's disease and other tauopathies, with all evaluated extracts being labeled by patient sera. Both low molecular weight fragments and high molecular weight aggregates were labeled. The same was seen in histological assessment, where patient sera were able to stain tau pathology in brains with Alzheimer's disease, corticobasal degeneration, progressive supranuclear palsy, and Pick's disease, highlighting the fact that the targeted conformational epitopes in the microtubule-binding region of tau represent a common denominator of tau pathology in a wide range of tauopathies (Novak et al., 2018a).

While the phase 1 trials were not designed as efficacy studies, inter-individual differences in AADvac1-induced antibody titres allowed the comparison between the strength of the antibody response and disease progression. A trend toward slower cognitive decline and lower hippocampal atrophy rate was observed in patients with higher titres (Novak et al., 2018a).
The safety profile in both studies was benign, with local injection site reactions being the only adverse event clearly tied to treatment (Novak et al., 2017, 2018a). The accruing results on AADvac1, and the fact that no drastic safety concerns are being reported for ACI-35 either indicate that active immunization can be a safe way to address tau pathology. The safety aspect will become increasingly important once the indication for active tau-targeted immunotherapies progresses from treating neurodegeneration toward preventing it.

\section{IMMUNE SENESCENCE}

With active immunotherapies, an additional layer of complexity is added to development. The immunogen itself is not the molecule that is meant to mediate the therapeutic effect; rather, the antibodies induced by vaccination are the active agent. A vaccine depends on the patient's immune system to deliver these antibodies, yet the vast majority of patients suffering from neurodegenerative disease are elderly, and their immune system senescent (Siegrist and Aspinall, 2009). Thus, a profound understanding of immunological mechanisms in the elderly is of paramount importance to ensure adequate antibody production, or to identify patients who can and who cannot benefit from a certain immunotherapy.

In the phase 1 study of AADvac1, we have investigated a range of lymphocyte populations, and evaluated their correlations with the antibody titres achieved at the end of the initial vaccination regimen (i.e., six doses in monthly intervals). The patient with the highest response had a $\sim 40 \times$ greater antibody titre than the patient who had the lowest IgG response. This diversity in response could, to an extent, be explained by differences in lymphocyte counts, T-helper cells counts, and the percentage off lymphocytes and neutrophil granulocytes (Novak et al., 2017). The ratio of lymphocytes to neutrophils could be interpreted as the immune system's overall predisposition toward a $\mathrm{T}_{\mathrm{H}} 1$ or $\mathrm{T}_{\mathrm{H}} 2$ type of response, with the latter being more conductive toward an antibodymediated response. The phase 1 dataset of 30 patients (with a sole non-responder) was too small to identify a cut-off for non-responders; it may be possible to establish one based on the ongoing phase 2 study (NCT02579252). Immunological cutoffs could be useful for the enrichment of trial populations for active immunotherapies. Immunological characterization of populations in clinical trials of immunotherapies could further promote the comparability of studies, and provide another important level of demographic information, analogous to age, sex, and ApoE genotype.

Another part of immune senescence applies equally to active and passive immunotherapies - that of the innate immune system (microglial senescence in particular) (Streit and Xue, 2014; Streit et al., 2014). Aged microglia undergo transformation from ramified to amoeboid morphology. They display a pro-inflammatory phenotype producing several inflammatory cytokines (Udeochu et al., 2016). An extensive genetic and proteomic study on aged microglia revealed that several pathways are deregulated during the aging of brain microglia including 
phagosome and endosome pathways, interferon signaling and antigen processing and presentation (Olah et al., 2018). If phagocytosis and antigen presentation are an inherent part of a vaccines or an antibody's pharmacodynamics, then microglial senescence could introduce further variance into the response to therapy. Markers of microglial senescence in the CSF or periphery yet have to be identified, yet will be extremely useful in explaining variability in the treatment responses to tau-targeted immunotherapies.

\section{VACCINE DESIGN}

To avoid a deleterious T-cell response aimed at a self-antigen, as seen with the first anti-amyloid- $\beta$ vaccine AN-1792 (Gilman et al., 2005), the viable approaches are either to outsource costimulatory T-cell epitopes to a carrier, as done for CAD-106 (Winblad et al., 2012) and AADvac1 (Kontsekova et al., 2014a, Novak et al., 2017), or to induce a T-cell independent antibody response (Theunis et al., 2013).

For T-cell dependent responses, the age-dependent reduction in T-cell repertoire (Britanova et al., 2014) is a challenge, yet can be overcome by adequate carrier selection. Carriers that present a great diversity of potential T-cell epitopes (e.g., KLH with its $400 \mathrm{kDa}$ mass and minimal sequence similarity to humans) have a higher chance to be recognized at all. Another option is to use carriers which could benefit from existing immunological memory [e.g., tetanus toxoid (Pichichero, 2013), or artificial carriers that feature a broad spectrum of T-cell epitopes from various antigens (Davtyan et al., 2017)]. It is possible that early issues with the immunogenicity of the CAD106 vaccine were caused by the low epitope diversity of the bacteriophage $\mathrm{Q} \beta$ carrier (Winblad et al., 2012).

Adjuvants are an essential component of active vaccines. For AADvac1, we have selected aluminum hydroxide (Novak et al., 2017) as aclassic $\mathrm{T}_{\mathrm{H}} 2$ response promoting adjuvant that performed well inpre-clinical studies, but the possibilities recently have expanded asthe field turns its attention to novel adjuvants. A limitation is that most of the novel adjuvantsfavor a $\mathrm{T}_{\mathrm{H}} 1$ response (Reed et al., 2013).

Ideally, each antigen should be tested with multiple carriers and adjuvants in humans to optimize the antibody response (Della Cioppa et al., 2015); as there in only so much we can learn from animal and in vitro studies about how the immune system of elderly humans operates, an empirical approach is warranted. On the other hand, full factorial study designs run into feasibility issues with the addition of further carriers and adjuvants as the number of study arms quickly grows unmanageable and statistical multiplicity increasingly obscures findings. A challenge for immunogenicity optimization in active immunotherapy is the need to assess immunogenicity in the target population, i.e., $\mathrm{AD} /$ tauopathy patients. It is known

\section{REFERENCES}

Agadjanyan, M. G., Petrovsky, N., and Ghochikyan, A. (2015). A fresh perspective from immunologists and vaccine researchers: active vaccination strategies to prevent and reverse Alzheimer's disease. Alzheimers Dement 11, 1246-1259. doi: 10.1016/j.jalz.2015.06.1884 that with increasing age, immunological health plays an everincreasing role in maintaining cognitive health; it is likely that Alzheimer patients will differ from cognitively healthy elderly also in their immune competence. Furthermore, the risk-benefit ratio for healthy elderly differs from dementia patients as the response to active vaccines cannot be easily terminated.

\section{CONCLUSION}

The development of tau-targeted immunotherapies has recently entered an exciting period of rampant growth and innovation. At this early stage, much of the learning is empirical. To maximize the knowledge obtained from these early trials, certain methodological and reporting standards should be implemented, both for preclinical and clinical research. Animal models and patient populations should be well-characterized; so should the epitopes of immunotherapies and their mechanisms of action (putative and proven). The greatest benefit to the field would be a thorough characterization of the diseased tau proteome - what molecular properties are found in individual tau species, where these species are located (cellular compartment/extracellular), and what their effects are. This is certainly a daunting, Herculean feat, but of immense value for the understanding of the mechanism of tau-targeted therapies: "What portion of tau does an immunotherapy affect? How? What is the impact on the physiological and pathophysiological function of tau? What human data have been used to confirm this?"

The immunotherapies currently in clinical development appear to be based on a range of philosophies - from an overall reduction of tau, to inhibition of aggregation, and cellmediated tauon clearance. The targeted epitopes similarly differ, with three broad groups (N-terminus, mid-domain and MTBR, and C-terminus) emerging. With minimal data, clinical or otherwise, being available at this stage of development, in-depth comparisons are not possible. Greater transparency in the field would promote the development of therapies, and shorten the time until we are able to offer an efficacious therapy to tauopathy patients.

\section{AUTHOR CONTRIBUTIONS}

All authors listed have made a substantial, direct and intellectual contribution to the work, and approved it for publication.

\section{FUNDING}

This work was supported by EU structural funds ITMS 26240220046.

Alzheimer, A. (1907). Über eine eigenartige Erkrankung der Hirnrinde. Allgemeine Z. Psychiatr. Psychisch Gerichtliche Med. 64, 146-148.

Arif, M., Kazim, S. F., Grundke-Iqbal, I., Garruto, R. M., and Iqbal, K. (2014). Tau pathology involves protein phosphatase $2 \mathrm{~A}$ in parkinsonism-dementia of Guam. Proc. Natl. Acad. Sci. U.S.A. 111, 1144-1149. doi: 10.1073/pnas. 1322614111 
Armstrong, M. J., et al. (2013). Criteria for the diagnosis of corticobasal degeneration. Neurology 80, 496-503.

Audouard, E., Houben, S., Masaracchia, C., Yilmaz, Z., Suain, V., Authelet, M., et al. (2016). High-molecular-weight paired helical filaments from alzheimer brain induces seeding of wild-type mouse Tau into an Argyrophilic 4R Tau Pathology in vivo. Am. J. Pathol. 186, 2709-2722. doi: 10.1016/j.ajpath.2016. 06.008

Avila, J., Jiménez, J. S., Sayas, C. L., Bolós, M., Zabala, J. C., Rivas, G., et al. (2016). Tau structures. Front. Aging Neurosci. 8:262. doi: 10.3389/fnagi.2016.00262

Balch, W. E., Morimoto, R. I., Dillin, A., and Kelly, J. W. (2008). Adapting proteostasis for disease intervention. Science 319, 916-919.

Baumgart, M., Snyder, H. M., Carrillo, M. C., Fazio, S., Kim, H., and Johns, H. (2015). Summary of the evidence on modifiable risk factors for cognitive decline and dementia: a population-based perspective. Alzheimers Dement 11, 718-726.

Bejanin, A., Schonhaut, D. R., La Joie, R., Kramer, J. H., Baker, S. L., Sosa, N., et al. (2017). Tau pathology and neurodegeneration contribute to cognitive impairment in Alzheimer's disease. Brain 140, 3286-3300. doi: 10.1093/brain/ awx243

Binder, L. I., Guillozet-Bongaarts, A. L., Garcia-Sierra, F., and Berry, R. W. (2005). Tau, tangles, and Alzheimer's disease. Biochim. Biophys. Acta 1739, 216-223.

Blennow, K., de Leon, M. J., and Zetterberg, H. (2006). Alzheimer's disease. Lancet $368,387-403$.

Bolognin, S., Blanchard, J., Wang, X., Basurto-Islas, G., Tung, Y. C., Kohlbrenner, E., et al. (2012). An experimental rat model of sporadic Alzheimer's disease and rescue of cognitive impairment with a neurotrophic peptide. Acta Neuropathol. 123, 133-151. doi: 10.1007/s00401-011-0908-x

Bournazos, S., DiLillo, D. J., and Ravetch, J. V. (2015). The role of Fc-FcgammaR interactions in IgG-mediated microbial neutralization. J. Exp. Med. 212, 1361-1369. doi: 10.1084/jem.20151267

Braak, E., Braak, H., and Mandelkow, E. M. (1994). A sequence of cytoskeleton changes related to the formation of neurofibrillary tangles and neuropil threads. Acta Neuropathol. 87, 554-567.

Braak, H., and Braak, E. (1991). Neuropathological stageing of Alzheimer-related changes. Acta Neuropathol. 82, 239-259.

Braak, H., and Del Tredici, K. (2011). The pathological process underlying Alzheimer's disease in individuals under thirty. Acta Neuropathol. 121, 171-181. doi: 10.1007/s00401-010-0789-4

Braak, H., Rüb, U., Schultz, C., and Del Tredici, K. (2006). Vulnerability of cortical neurons to Alzheimer's and Parkinson's diseases. J Alzheimers Dis. 9, $35-44$.

Bright, J., Hussain, S., Dang, V., Wright, S., Cooper, B., Byun, T., et al. (2015). Human secreted tau increases amyloid-beta production. Neurobiol. Aging 36, 693-709. doi: 10.1016/j.neurobiolaging.2014.09.007

Britanova, O. V., Putintseva, E. V., Shugay, M., Merzlyak, E. M., Turchaninova, M. A., Staroverov, D. B., et al. (2014). Age-related decrease in TCR repertoire diversity measured with deep and normalized sequence profiling. J. Immunol. 192, 2689-2698. doi: 10.4049/jimmunol.1302064

Clavaguera, F., Bolmont, T., Crowther, R. A., Abramowski, D., Frank, S., Probst, A., et al. (2009). Transmission and spreading of tauopathy in transgenic mouse brain. Nat. Cell Biol. 11, 909-913. doi: 10.1038/ncb1901

Courade, J. P., Angers, R., Mairet-Coello, G., Pacico, N., Tyson, K., Lightwood, D., et al. (2018). Epitope determines efficacy of therapeutic anti-Tau antibodies in a functional assay with human Alzheimer Tau. Acta Neuropathol. doi: 10.1007/ s00401-018-1911-2 [Epub ahead of print].

Crowther, R. A., and Goedert, M. (2000). Abnormal tau-containing filaments in neurodegenerative diseases. J. Struct. Biol. 130, 271-279.

Czerkovicz, J., Chen, W., Wang, Q., Shen, C., Wager, C., Stone, I., et al. (2018). Pan-Tau Antibody Biib076 exhibits promising safety and biomarker profile in cynomolgus monkey toxicity study. Alzheimers Dementia 13:1271.

Davtyan, H., Chen, W. W., Zagorski, K., Davis, J., Petrushina, I., Kazarian, K., et al. (2017). MultiTEP platform-based DNA epitope vaccine targeting $\mathrm{N}$-terminus of tau induces strong immune responses and reduces tau pathology in THY-Tau22 mice. Vaccine 35, 2015-2024. doi: 10.1016/j.vaccine.2017.03.020

Della Cioppa, G., Jonsdottir, I., and Lewis, D. (2015). Challenges in early clinical development of adjuvanted vaccines. Vaccine 33(Suppl. 2), B47-B51. doi: $10.1016 /$ j.vaccine.2015.02.031
Dickson, D. W., Kouri, N., Murray, M. E., and Josephs, K. A. (2011). Neuropathology of frontotemporal lobar degeneration-tau (FTLD-tau). J. Mol. Neurosci. 45, 384-389. doi: 10.1007/s12031-011-9589-0

Evans, L. D., Wassmer, T., Fraser, G., Smith, J., Perkinton, M., Billinton, A., et al. (2018). Extracellular monomeric and aggregated Tau efficiently enter human neurons through overlapping but distinct pathways. Cell Rep. 22, 3612-3624. doi: 10.1016/j.celrep.2018.03.021

Falcon, B., Zhang, W., Murzin, A. G., Murshudov, G., Garringer, H. J., Vidal, R., et al. (2018). Structures of filaments from Pick's disease reveal a novel tau protein fold. Nature 561, 137-140. doi: 10.1038/s41586-018-0454-y

Filipcik, P., Zilka, N., Bugos, O., Kucerak, J., Koson, P., Novak, P., et al. (2012). First transgenic rat model developing progressive cortical neurofibrillary tangles. Neurobiol. Aging 33, 1448-1456. doi: 10.1016/j.neurobiolaging. 2010.10.015

Fitzpatrick, A. W. P., et al. (2017). Cryo-EM structures of tau filaments from Alzheimer's disease. Nature 547, 185-190.

Forest, S. K., Acker, C. M., d'Abramo, C., and Davies, P. (2013). Methods for measuring tau pathology in transgenic mouse models. J. Alzheimers Dis. 33, 463-471. doi: 10.3233/JAD-2012-121354

Ghezzo, A., Salvioli, S., Solimando, M. C., Palmieri, A., Chiostergi, C., Scurti, M., et al. (2014). Age-related changes of adaptive and neuropsychological features in persons with down syndrome. PLoS One 9:e113111. doi: 10.1371/journal.pone. 0113111

Gilman, S., Koller, M., Black, R. S., Jenkins, L., Griffith, S. G., Fox, N. C., et al. (2005). Clinical effects of Abeta immunization (AN1792) in patients with AD in an interrupted trial. Neurology 64, 1553-1562.

Gómez-Isla, T., Hollister, R., West, H., Mui, S., Growdon, J. H., Petersen, R. C. et al. (1997). Neuronal loss correlates with but exceeds neurofibrillary tangles in Alzheimer's disease. Ann. Neurol. 41, 17-24.

Gorno-Tempini, M. L., Hillis, A. E., Weintraub, S., Kertesz, A., Mendez, M., Cappa, S. F., et al. (2011). Classification of primary progressive aphasia and its variants. Neurology 76, 1006-1014. doi: 10.1212/WNL.0b013e31821103e6

Grinberg, L. T., and Heinsen, H. (2009). Argyrophilic grain disease: an update about a frequent cause of dementia. Dement Neuropsychol. 3, 2-7. doi: 10.1590/ S1980-57642009DN30100002

Grundke-Iqbal, I., Iqbal, K., Tung, Y. C., Quinlan, M., Wisniewski, H. M., and Binder, L. I., (1986). Abnormal phosphorylation of the microtubule-associated protein tau (tau) in Alzheimer cytoskeletal pathology. Proc. Natl. Acad. Sci. U.S.A. 83, 4913-4917.

Gsponer, J., Futschik, M. E., Teichmann, S. A., and Babu, M. M. (2008). Tight regulation of unstructured proteins: from transcript synthesis to protein degradation. Science 322, 1365-1368. doi: 10.1126/science.1163581

Gu, J., Congdon, E. E., and Sigurdsson, E. M. (2013). Two novel Tau antibodies targeting the 396/404 region are primarily taken up by neurons and reduce Tau protein pathology. J. Biol. Chem. 288, 33081-33095. doi: 10.1074/jbc.M113. 494922

Guo, J. L., Narasimhan, S., Changolkar, L., He, Z., Stieber, A., Zhang, B., et al. (2016). Unique pathological tau conformers from Alzheimer's brains transmit tau pathology in nontransgenic mice. J. Exp. Med. 213, 2635-2654.

Heneka, M. T., Carson, M. J., El Khoury, J., Landreth, G. E., Brosseron, F., Feinstein, D. L., et al. (2015). Neuroinflammation in Alzheimer's disease. Lancet Neurol. 14, 388-405.

Hernandez, F., Cuadros, R., Ollá, I., García, C., Ferrer, I., Perry, G., et al. (2018). Differences in structure and function between human and murine tau. Biochim. Biophys. Acta Mol. Basis Dis. (in press).

Hodges, J. R., Davies, R. R., Xuereb, J. H., Casey, B., Broe, M., Bak, T. H., et al. (2004). Clinicopathological correlates in frontotemporal dementia. Ann. Neurol. 56, 399-406.

Hof, P. R., Bouras, C., Perl, D. P., Sparks, D. L., Mehta, N., and Morrison, J. H. (1995). Age-related distribution of neuropathologic changes in the cerebral cortex of patients with Down's syndrome. Quantitative regional analysis and comparison with Alzheimer's disease. Arch. Neurol. 52, 379-391.

Horiguchi, T., Uryu, K., Giasson, B. I., Ischiropoulos, H., LightFoot, R., Bellmann, C., et al. (2003). Nitration of tau protein is linked to neurodegeneration in tauopathies. Am. J. Pathol. 163, 1021-1031.

Iqbal, K., Liu, F., and Gong, C. X. (2016). Tau and neurodegenerative disease: the story so far. Nat. Rev. Neurol. 12, 15-27. doi: 10.1038/nrneurol. 2015.225 
Ittner, A., and Ittner, L. M. (2018). Dendritic Tau in Alzheimer's Disease. Neuron 99, 13-27.

Jack, CR Jr, Bennett, D. A., Blennow, K., Carrillo, M. C., Dunn, B., Haeberlein, S. B., et al. (2018). NIA-AA research framework: toward a biological definition of Alzheimer's disease. Alzheimers Dement 14, 535-562. doi: 10.1016/j.jalz.2018. 02.018

Jellinger, K. A., and Attems, J. (2007). Neurofibrillary tangle-predominant dementia: comparison with classical Alzheimer disease. Acta Neuropathol. 113, 107-117.

Jellinger, K. A., and Bancher, C. (1998). Senile dementia with tangles (tangle predominant form of senile dementia). Brain Pathol. 8, 367-376.

Jicha, G. A., Bowser, R., Kazam, I. G., and Davies, P. (1997). Alz-50 and MC1 , a new monoclonal antibody raised to paired helical filaments, recognize conformational epitopes on recombinant tau. J. Neurosci. Res. 48, 128-132.

Josephs, K. A., Hodges, J. R., Snowden, J. S., Mackenzie, I. R., Neumann, M., Mann, D. M., et al. (2011). Neuropathological background of phenotypical variability in frontotemporal dementia. Acta Neuropathol. 122, 137-153. doi: 10.1007/s00401-011-0839-6

Josephs, K. A., Petersen, R. C., Knopman, D. S., Boeve, B. F., Whitwell, J. L., Duffy, J. R., et al. (2006). Clinicopathologic analysis of frontotemporal and corticobasal degenerations and PSP. Neurology 66, 41-48.

Kanaan, N. M., Pigino, G. F., Brady, S. T., Lazarov, O., Binder, L. I., and Morfini, G. A. (2013). Axonal degeneration in Alzheimer's disease: when signaling abnormalities meet the axonal transport system. Exp. Neurol. 246, 44-53. doi: 10.1016/j.expneurol.2012.06.003

Klein, C., Kramer, E. M., Cardine, A. M., Schraven, B., Brandt, R., and Trotter, J. (2002). Process outgrowth of oligodendrocytes is promoted by interaction of fyn kinase with the cytoskeletal protein tau. J. Neurosci. 22, 698-707.

Kontsekova, E., Zilka, N., Kovacech, B., Novak, P., and Novak, M. (2014a). First-inman tau vaccine targeting structural determinants essential for pathological tautau interaction reduces tau oligomerisation and neurofibrillary degeneration in an Alzheimer's disease model. Alzheimers Res. Ther. 6:44. doi: 10.1186/ alzrt278

Kontsekova, E., Zilka, N., Kovacech, B., Skrabana, R., and Novak, M. (2014b). Identification of structural determinants on tau protein essential for its pathological function: novel therapeutic target for tau immunotherapy in Alzheimer's disease. Alzheimers Res. Ther. 6:45. doi: 10.1186/alzrt277

Korenova, M., Zilka, N., Stozicka, Z., Bugos, O., Vanicky, I., and Novak, M. (2009). NeuroScale, the battery of behavioral tests with novel scoring system for phenotyping of transgenic rat model of tauopathy. J. Neurosci. Methods 177, 108-114. doi: 10.1016/j.jneumeth.2008.09.027

Koson, P., Zilka, N., Kovac, A., Kovacech, B., Korenova, M., Filipcik, P., et al. (2008). Truncated tau expression levels determine life span of a rat model of tauopathy without causing neuronal loss or correlating with terminal neurofibrillary tangle load. Eur. J. Neurosci. 28, 239-246. doi: 10.1111/j.14609568.2008.06329.x

Kovac, A., Zilka, N., Kazmerova, Z., Cente, M., Zilkova, M., and Novak, M. (2011). Misfolded truncated protein tau induces innate immune response via MAPK pathway. J. Immunol. 187, 2732-2739. doi: 10.4049/jimmunol.1100216

Kovacech, B., Skrabana, R., and Novak, M. (2010). Transition of tau protein from disordered to misordered in Alzheimer's disease. Neurodegener. Dis. 7, 24-27. doi: $10.1159 / 000283478$

Ksiezak-Reding, H., and Wall, J. S. (2005). Characterization of paired helical filaments by scanning transmission electron microscopy. Microsc. Res. Tech. 67, 126-140.

Lambert, J. C., Ibrahim-Verbaas, C. A., Harold, D., Naj, A. C., Sims, R., Bellenguez, C., et al. (2013). Meta-analysis of 74,046 individuals identifies 11 new susceptibility loci for Alzheimer's disease. Nat. Genet. 45, 1452-1458. doi: $10.1038 / \mathrm{ng} .2802$

Ledesma, M. D., Bonay, P., Colaço, C., and Avila, J. (1994). Analysis of microtubule-associated protein tau glycation in paired helical filaments. J. Biol. Chem. 269, 21614-21619.

Lee, S. H., Le, Pichon CE, Adolfsson, O., Gafner, V., Pihlgren, M., Lin, H., et al. (2016). Antibody-mediated targeting of tau in vivo does not require effector function and microglial engagement. Cell Rep. 16, 1690-1700. doi: 10.1016/j. celrep.2016.06.099
Levin, J., Kurz, A., Arzberger, T., Giese, A., and Höglinger, G. U. (2016). The differential diagnosis and treatment of atypical parkinsonism. Dtsch. Arztebl. Int. 113, 61-69.

Lopes, S., Vaz-Silva, J., Pinto, V., Dalla, C., Kokras, N., Bedenk, B., et al. (2016). Tau protein is essential for stress-induced brain pathology. Proc. Natl. Acad. Sci. U.S.A. 113, E3755-E3763. doi: 10.1073/pnas.1600953113

Maass, A., Lockhart, S. N., Harrison, T. M., Bell, R. K., Mellinger, T., Swinnerton, K., et al. (2018). Entorhinal tau pathology, episodic memory decline, and neurodegeneration in aging. J. Neurosci. 38, 530-543. doi: 10.1523/ JNEUROSCI.2028-17.2017

Majounie, E., Cross, W., Newsway, V., Dillman, A., Vandrovcova, J., Morris, C. M., et al. (2013). Variation in tau isoform expression in different brain regions and disease states. Neurobiol. Aging 34, 1922.e7-1922.e12.

Marciniak, E., Leboucher, A., Caron, E., Ahmed, T., Tailleux, A., Dumont, J., et al. (2017). Tau deletion promotes brain insulin resistance. J. Exp. Med. 214, 2257-2269. doi: 10.1084/jem.20161731

McKee, A. C., et al. (2013). The spectrum of disease in chronic traumatic encephalopathy. Brain 136(Pt 1), 43-64.

Menkes-Caspi, N., Yamin, H. G., Kellner, V., Spires-Jones, T. L., Cohen, D., and Stern, E. A. (2015). Pathological tau disrupts ongoing network activity. Neuron 85, 959-966. doi: 10.1016/j.neuron.2015.01.025

Méphon-Gaspard, A., Boca, M., Pioche-Durieu, C., Desforges, B., Burgo, A., Hamon, L., et al. (2016). Role of tau in the spatial organization of axonal microtubules: keeping parallel microtubules evenly distributed despite macromolecular crowding. Cell Mol. Life Sci. 73, 3745-3760. doi: 10.1007/ s00018-016-2216-z

Mohamed, N. V., Plouffe, V., Rémillard-Labrosse, G., Planel, E., and Leclerc, N. (2014). Starvation and inhibition of lysosomal function increased tau secretion by primary cortical neurons. Sci. Rep. 4:5715. doi: 10.1038/srep 05715

Morawski, M., Brückner, G., Jäger, C., Seeger, G., and Arendt, T. (2010). Neurons associated with aggrecan-based perineuronal nets are protected against tau pathology in subcortical regions in Alzheimer's disease. Neuroscience 169, 1347-1363. doi: 10.1016/j.neuroscience.2010.05.022

Mori, H., Kondo, J., and Ihara, Y. (1987). Ubiquitin is a component of paired helical filaments in Alzheimer's disease. Science 235, 1641-1644.

Morris, J. C., Blennow, K., Froelich, L., Nordberg, A., Soininen, H., Waldemar, G., et al. (2014). Harmonized diagnostic criteria for Alzheimer's disease: recommendations. J. Intern. Med. 275, 204-213. doi: 10.1111/ joim. 12199

Mudher, A., Colin, M., Dujardin, S., Medina, M., Dewachter, I., Alavi, Naini SM, et al. (2017). What is the evidence that tau pathology spreads through prionlike propagation? Acta Neuropathol. Commun. 5:99. doi: 10.1186/s40478-0170488-7

Murray, M. E., Lowe, V. J., Graff-Radford, N. R., Liesinger, A. M., Cannon, A., Przybelski, S. A., et al. (2015). Clinicopathologic and 11C-Pittsburgh compound $\mathrm{B}$ implications of Thal amyloid phase across the Alzheimer's disease spectrum. Brain 138(Pt 5), 1370-1381. doi: 10.1093/brain/awv050

Nelson, P. T., Alafuzoff, I., Bigio, E. H., Bouras, C., Braak, H., Cairns, N. J., et al. (2012). Correlation of Alzheimer disease neuropathologic changes with cognitive status: a review of the literature. J. Neuropathol. Exp. Neurol. 71, 362-381. doi: 10.1097/NEN.0b013e31825018f7

Nobuhara, C. K., DeVos, S. L., Commins, C., Wegmann, S., Moore, B. D., Roe, A. D., et al. (2017). Tau antibody targeting pathological species blocks neuronal uptake and interneuron propagation of Tau in vitro. Am. J. Pathol. 187, 1399-1412. doi: 10.1016/j.ajpath.2017.01.022

Novak, M., Kabat, J., and Wischik, C. M. (1993). Molecular characterization of the minimal protease resistant tau unit of the Alzheimer's disease paired helical filament. EMBO J. 12, 365-370.

Novak, P., Cehlar, O., Skrabana, R., and Novak, M. (2018a). FUNDAMANT: an interventional 72-week phase 1 follow study of AADvac1, an active immunotherapy against tau protein pathology in Alzheimer's disease. Alzheimers Res. Ther. (in press).

Novak, P., Cehlar, O., Skrabana, R., and Novak, M. (2018b). Tau conformation as a target for disease-modifying therapy: the role of truncation. J. Alzheimers Dis. 64, S535-S546. doi: 10.3233/JAD- 179942 
Novak, P., Prcina, M., and Kontsekova, E. (2011). Tauons and prions: infamous cousins? J. Alzheimers Dis. 26, 413-430. doi: 10.3233/JAD-2011110194

Novak, P., Schmidt, R., Kontsekova, E., Zilka, N., Kovacech, B., Skrabana, R., et al. (2017). Safety and immunogenicity of the tau vaccine AADvacl in patients with Alzheimer's disease: a randomised, double-blind, placebo-controlled, phase 1 trial. Lancet Neurol. 16, 123-134. doi: 10.1016/S1474-4422(16) 30331-3

Olah, M., Patrick, E., Villani, A. C., Xu, J., White, C. C., Ryan, K. J., et al. (2018). A transcriptomic atlas of aged human microglia. Nat. Commun. 9:539. doi: 10.1038/s41467-018-02926-5

Opattova, A., Filipcik, P., Cente, M., and Novak, M. (2013). Intracellular degradation of misfolded tau protein induced by geldanamycin is associated with activation of proteasome. J. Alzheimers Dis. 33, 339-348. doi: 10.3233/ JAD-2012-121072

Paholikova, K., Salingova, B., Opattova, A., Skrabana, R., Majerova, P., Zilka, N., et al. (2014). N-terminal truncation of microtubule associated protein tau dysregulates its cellular localization. J. Alzheimers Dis. 43, 915-926. doi: 10.3233/JAD-140996

Pichichero, M. E. (2013). Protein carriers of conjugate vaccines: characteristics, development, and clinical trials. Hum. Vaccin. Immunother. 9, 2505-2523.

Poorkaj, P., Bird, T. D., Wijsman, E., Nemens, E., Garruto, R. M., Anderson, L., et al. (1998). Tau is a candidate gene for chromosome 17 frontotemporal dementia. Ann. Neurol. 43, 815-825.

Reed, S. G., Orr, M. T., and Fox, C. B. (2013). Key roles of adjuvants in modern vaccines. Nat. Med. 19, 1597-1608. doi: 10.1038/nm.3409

Respondek, G., and Hoglinger, G. U. (2016). The phenotypic spectrum of progressive supranuclear palsy. Parkinsonism Relat. Disord. 22(Suppl. 1), S34-S36.

Rissman, R. A., Staup, M. A., Lee, A. R., Justice, N. J., Rice, K. C., Vale, W., et al. (2012). Corticotropin-releasing factor receptor-dependent effects of repeated stress on tau phosphorylation, solubility, and aggregation. Proc. Natl. Acad. Sci. U.S.A. 109, 6277-6282. doi: 10.1073/pnas.1203140109

Robinson, J. L., Molina-Porcel, L., Corrada, M. M., Raible, K., Lee, E. B., Lee, V. M., et al. (2014). Perforant path synaptic loss correlates with cognitive impairment and Alzheimer's disease in the oldest-old. Brain 137(Pt 9), 2578-2587. doi: 10.1093/brain/awu190

Rodriguez, R. D., Suemoto, C. K., Molina, M., Nascimento, C. F., Leite, R. E., de Lucena Ferretti-Rebustini, R. E., et al. (2016). Argyrophilic grain disease: demographics, clinical, and neuropathological features from a large autopsy study. J. Neuropathol. Exp. Neurol. 75, 628-635. doi: 10.1093/jnen/nlw034

Sarkar, M., Kuret, J., and Lee, G. (2008). wo motifs within the tau microtubulebinding domain mediate its association with the hsc70 molecular chaperone. J. Neurosci. Res. 86, 2763-2773. doi: 10.1002/jnr.21721

Sato, C., Barthélemy, N. R., Mawuenyega, K. G., Patterson, B. W., Gordon, B. A., Jockel-Balsarotti, J., et al. (2018). Tau Kinetics in Neurons and the Human Central Nervous System. Neuron 98, 861-864.

Saxena, A., and $\mathrm{Wu}, \mathrm{D}$. (2016). Advances in therapeutic Fc engineering modulation of IgG-associated effector functions and serum half-life. Front. Immunol. 7:580. doi: 10.3389/fimmu.2016.00580

Schuurman, J., Van, Ree R, Perdok, G. J., Van, Doorn HR, Tan, K. Y., and Aalberse, R. C. (1999). Normal human immunoglobulin G4 is bispecific: it has two different antigen-combining sites. Immunology 97, 693-698.

Seilhean, D., Le, Ber I, Sarazin, M., Lacomblez, L., Millecamps, S., Salachas, F., et al. (2011). Fronto-temporal lobar degeneration: neuropathology in 60 cases. J. Neural. Transm. 118, 753-764. doi: 10.1007/s00702-011-0649-y

Sergeant, N., Delacourte, A., and Buee, L. (2005). Tau protein as a differential biomarker of tauopathies. Biochim. Biophys. Acta 1739, 179-197.

Sieben, A., Van Langenhove, T., Engelborghs, S., Martin, J. J., Boon, P., Cras, P., et al. (2012). The genetics and neuropathology of frontotemporal lobar degeneration. Acta Neuropathol. 124, 353-372.

Siegrist, C. A., and Aspinall, R. (2009). B-cell responses to vaccination at the extremes of age. Nat. Rev. Immunol. 9, 185-194. doi: 10.1038/nri2508

Skrabana, R., Kovacech, B., Filipcik, P., Zilka, N., Jadhav, S., Smolek, T., et al. (2017). Neuronal expression of truncated tau efficiently promotes neurodegeneration in animal models: pitfalls of toxic oligomer analysis. J. Alzheimers Dis. 58, 1017-1025. doi: 10.3233/JAD-161124
Smith, A. M., and Dragunow, M. (2014). The human side of microglia. Trends Neurosci. 37, 125-135.

Spillantini, M. G., and Goedert, M. (2013). Tau pathology and neurodegeneration. Lancet Neurol. 12, 609-622.

Stel, V. S., Dekker, F. W., Tripepi, G., Zoccali, C., and Jager, K. J. (2011). Survival analysis I: the Kaplan-Meier method. Nephron Clin. Pract. 119, c83-c88. doi: $10.1159 / 000324758$

Stozicka, Z., Zilka, N., Novak, P., Kovacech, B., Bugos, O., and Novak, M. (2010). Genetic background modifies neurodegeneration and neuroinflammation driven by misfolded human tau protein in rat model of tauopathy: implication for immunomodulatory approach to Alzheimer's disease. J. Neuroinflammation 7:64. doi: 10.1186/1742-2094-7-64

Streit, W. J., Braak, H., Xue, Q. S., and Bechmann, I. (2009). Dystrophic (senescent) rather than activated microglial cells are associated with tau pathology and likely precede neurodegeneration in Alzheimer's disease. Acta Neuropathol. 118, 475-485. doi: 10.1007/s00401-009-0556-6

Streit, W. J., Xue, Q. S., Tischer, J., and Bechmann, I. (2014). Microglial pathology. Acta Neuropathol. Commun. 2:142.

Streit, W. J., and Xue, Q. S. (2014). Human CNS immune senescence and neurodegeneration. Curr. Opin. Immunol. 29, 93-96. doi: 10.1016/j.coi.2014. 05.005

Tai, H. C., Serrano-Pozo, A., Hashimoto, T., Frosch, M. P., Spires-Jones, T. L., and Hyman, B. T. (2012). The synaptic accumulation of hyperphosphorylated tau oligomers in Alzheimer disease is associated with dysfunction of the ubiquitinproteasome system. Am. J. Pathol. 181, 1426-1435. doi: 10.1016/j.ajpath.2012. 06.033

Theunis, C., Adolfsson, O., Crespo-Biel, N., Piorkowska, K., Pihlgren, M., Hickman, D. T., et al. (2017). Novel phospho-tau monoclonal antibody generated using a liposomal vaccine, with enhanced recognition of a conformational tauopathy epitope. J. Alzheimers Dis. 56, 585-599. doi: 10.3233/ JAD- 160695

Theunis, C., Crespo-Biel, N., Gafner, V., Pihlgren, M., López-Deber, M. P., Reis, P., et al. (2013). Efficacy and safety of a liposome-based vaccine against protein Tau, assessed in tau.P301L mice that model tauopathy. PLoS One 8:e72301. doi: 10.1371/journal.pone.0072301

Udeochu, J. C., Shea, J. M., and Villeda, S. A. (2016). Microglia communication: Parallels between aging and Alzheimer's disease. Clin. Exp. Neuroimmunol. 7, 114-125.

Vallet, P. G., Guntern, R., Hof, P. R., Golaz, J., Delacourte, A., Robakis, N. K., et al. (1992). A comparative study of histological and immunohistochemical methods for neurofibrillary tangles and senile plaques in Alzheimer's disease. Acta Neuropathol. 83, 170-178.

Vidal, R., Frangione, B., Rostagno, A., Mead, S., Révész, T., Plant, G., et al. (1999). A stop-codon mutation in the BRI gene associated with familial British dementia. Nature 399, 776-781.

Vidarsson, G., Dekkers, G., and Rispens, T. (2014). IgG subclasses and allotypes: from structure to effector functions. Front. Immunol. 5:520. doi: 10.3389/ fimmu.2014.00520

von, Bergen M, Barghorn, S., Müller, S. A., Pickhardt, M., Biernat, J., Mandelkow, E. M., et al. (2006). The core of tau-paired helical filaments studied by scanning transmission electron microscopy and limited proteolysis. Biochemistry 45, 6446-6457.

von, Bergen M, Friedhoff, P., Biernat, J., Heberle, J., Mandelkow, E. M., and Mandelkow, E. (2000). Assembly of tau protein into Alzheimer paired helical filaments depends on a local sequence motif ((306)VQIVYK(311)) forming beta structure. Proc. Natl. Acad. Sci. U.S.A. 97, 5129-5134.

Wang, J. Z., Grundke-Iqbal, I., and Iqbal, K. (1996). Glycosylation of microtubuleassociated protein tau: an abnormal posttranslational modification in Alzheimer's disease. Nat. Med. 2, 871-875.

Wang, Y., and Mandelkow, E. (2016). Tau in physiology and pathology. Nat. Rev. Neurosci. 17, 5-21.

Warren, J. D., Rohrer, J. D., and Rossor, M. N. (2013). Clinical review. Frontotemporal dementia. BMJ 347:f4827. doi: 10.1136/bmj.f4827

Webster, S. J., Bachstetter, A. D., Nelson, P. T., Schmitt, F. A., and Van, Eldik LJ (2014). Using mice to model Alzheimer's dementia: an overview of the clinical disease and the preclinical behavioral changes in 10 mouse models. Front. Genet. 5:88. doi: 10.3389/fgene.2014.00088 
Weingarten, M. D., Lockwood, A. H., Hwo, S. Y., and Kirschner, M. W. (1975). A protein factor essential for microtubule assembly. Proc. Natl. Acad. Sci. U.S.A. $72,1858-1862$

West, M. J., Slomianka, L., and Gundersen, H. J. (1991). Unbiased stereological estimation of the total number of neurons in thesubdivisions of the rat hippocampus using the optical fractionator. Anat. Rec. 231, 482-497.

West, T., Hu, Y., Verghese, P. B., Bateman, R. J., Braunstein, J. B., Fogelman, I., et al. (2017). Preclinical and clinical development of ABBV-8E12, a humanized anti-tau antibody, for treatment of alzheimer's disease and other tauopathies. J. Prev. Alzheimers Dis. 4, 236-241. doi: 10.14283/jpad.2017.36

Winblad, B., Andreasen, N., Minthon, L., Floesser, A., Imbert, G., Dumortier, T., et al. (2012). Safety, tolerability, and antibody response of active Abeta immunotherapy with CAD106 in patients with Alzheimer's disease: randomised, double-blind, placebo-controlled, first-in-human study. Lancet Neurol. 11, 597-604. doi: 10.1016/S1474-4422(12)70140-0

Wischik, C. M., Novak, M., Thøgersen, H. C., Edwards, P. C., Runswick, M. J., Jakes, R., et al. (1988). Isolation of a fragment of tau derived from the core of the paired helical filament of Alzheimer disease. Proc. Natl. Acad. Sci. U.S.A. 85, 4506-4510.

Wolf, A., Bauer, B., Abner, E. L., Ashkenazy-Frolinger, T., and Hartz, A. M. (2016). A comprehensive behavioral test battery to assess learning and memory in 129S6/Tg2576 mice. PLoS One 11:e0147733. doi: 10.1371/journal.pone.0147733

Wszolek, Z. K., Tsuboi, Y., Ghetti, B., Pickering-Brown, S., Baba, Y., and Cheshire, W. P. (2006). Frontotemporal dementia and parkinsonism linked to chromosome 17 (FTDP-17). Orphanet J. Rare Dis. 1:30.

Yamada, K., Holth, J. K., Liao, F., Stewart, F. R., Mahan, T. E., Jiang, H., et al. (2014). Neuronal activity regulates extracellular tau in vivo. J. Exp. Med. 211, 387-393. doi: 10.1084/jem.20131685

Yanamandra, K., Jiang, H., Mahan, T. E., Maloney, S. E., Wozniak, D. F., Diamond, M. I., et al. (2015). Anti-tau antibody reduces insoluble tau and decreases brain atrophy. Ann. Clin. Transl. Neurol. 2, 278-288. doi: 10.1002/ acn 3.176

Yu, Y., Run, X., Liang, Z., Li, Y., Liu, F., Liu, Y., et al. (2009). Developmental regulation of tau phosphorylation, tau kinases, and tau phosphatases. J. Neurochem. 108, 1480-1494. doi: 10.1111/j.1471-4159.2009.05882.x

Zhou, Y., Shi, J., Chu, D., Hu, W., Guan, Z., Gong, C. X., et al. (2018). Relevance of phosphorylation and truncation of tau to the etiopathogenesis of Alzheimer's disease. Front. Aging Neurosci. 10:27. doi: 10.3389/fnagi. 2018.00027

Zilka, N., Filipcik, P., Koson, P., Fialova, L., Skrabana, R., Zilkova, M., et al. (2006). Truncated tau from sporadic Alzheimer's disease suffices to drive neurofibrillary degeneration in vivo. FEBS Lett. 580, 3582-3588.

Zilka, N., Kazmerova, Z., Jadhav, S., Neradil, P., Madari, A., Obetkova, D., et al. (2012a). Who fans the flames of Alzheimer's disease brains? Misfolded tau on the crossroad of neurodegenerative and inflammatory pathways. J. Neuroinflammation 9:47. doi: 10.1186/1742-2094-9-47

Zilka, N., Kovacech, B., Barath, P., Kontsekova, E., and Novák, M. (2012b). The self-perpetuating tau truncation circle. Biochem. Soc. Trans. 40, 681-686. doi: 10.1042/BST20120015

Conflict of Interest Statement: PN, EK, NZ and MN are employees of AXON Neuroscience SE or its subsidiaries.

Copyright (C) 2018 Novak, Kontsekova, Zilka and Novak. This is an open-access article distributed under the terms of the Creative Commons Attribution License (CC BY). The use, distribution or reproduction in other forums is permitted, provided the original author(s) and the copyright owner(s) are credited and that the original publication in this journal is cited, in accordance with accepted academic practice. No use, distribution or reproduction is permitted which does not comply with these terms. 